\title{
Justification of scripts of further development of agriculture in aspect of security of food safety
}

\author{
Artimonova I. \\ $\mathrm{PhD}$ in economics, assiaciate professor, \\ Bila Tserkva National Agrarian University
}

The purpose. To justify perspectives of stable development of domestic farm-production in the context of security of food safety of the country. Methods. Statistically-economic, structurally functional, monographic, table, sampling, relative, computing-constructive and regression analysis. Results. Calculation is made of the forecast commodity offer in a slit of principal views of the food in Ukraine on three alternatives. Normative necessity of investment resources is calculated at production of animal husbandry on the basis of determination of specifications of necessity in the basic, human and working capitals. The necessary volume of investments for production of main produce of agriculture for sufficing necessity of the country in reaching its food safety is determined. It is established that security of scientifically justified necessities of population in food stuffs demands reaching the balanced resource security of agricultural production and its intelligent use and heightening purchasing capacity of population of the country. Conclusions. Normative necessity in investment capital for production of animal husbandry with the purpose of reaching balance of resource security of production on the basis of implementation of innovative resources saving techniques and modernization of branches is specified, and also by development of target regional programs of development of agriculture.

Key words: agricultural production, resource security, rational norms of consumptions, fixed capital, specifications of investments, food safety.

Introduction. The strategic goal of the country's agricultural development is to provide food security, to satisfy the population with basic food products. Evaluating the disproportions in the food sector is an important part of the modern economic strategy, based on the priorities of macroeconomic stabilization and food security in Ukraine. The basis of ensuring food security of the country is the development of agro-food production, which is achieved through accelerated introduction of innovative technologies, modernization of the material and technical base of agriculture and food industry, as well as measures of an economic nature aimed at increasing the profitability of commodity producers and shaping the preconditions for economic growth. In the context of increasing crisis phenomena, the development of anti-crisis regulation measures is of paramount importance, where, at the first stage, it is important to ensure the balance of the components of the resource supply. It is the question of rational and balanced utilization of resource provision of agrarian production to be considered in the article.

The purpose of the study is to substantiate the forecast scenarios of the development of domestic agricultural production, which are oriented on food supply of the population of the country by main types of food products.

Research methodology. For realization of the set goal in scientific research the following methods were used: statistical-economic, structural-functional, monographic, tabular, selective, comparative, calculation-constructive and regression analysis.

Research results. It is known that food security is a state of food production in a country that can fully meet the needs of every member of society in food of the appropriate quality provided that it is balanced and economically affordable.

It was found that in 2014 the research department of The Economist magazine carried out an assessment of the level of food security of the countries of the world, bringing the US to the first place in the rating. In the opinion of the ranking compilers, a characteristic feature of the United States is 
economic sustainability, a high level of income, coupled with a relatively low share of household food costs, highly developed agricultural and logistic infrastructure, high diversification of food and the economic availability of the population to safe and nutritious food products. It should be noted that Ukraine in this ranking ranked 52 positions out of 109 [1].

The analysis of the reports of the Ministry of Economic Development and Trade of Ukraine on the state of food security of Ukraine for 2010-2015 shows the following key threats to the country's food security: unbalanced consumption of food by the population; low consumption of products of animal origin in the energy diet of the population; high share of household expenditures on foodstuffs in the structure of their total expenditures; reducing the capacity of the domestic market for certain food products; import dependence of the country on individual products; high differentiation of the cost of food by social groups; raw material export of agricultural products; increase of prices for agricultural products in the domestic market; slow implementation of international standards and food quality systems.

Compared to rational consumption norms during 2011-2015, Ukrainians were not prolonging $32-39 \%$ of meat and meat products, $42-46 \%$ of milk and dairy products and fruit and berry products by $42-47 \%$. However, compared to 2011 , meat and meat products decreased by $4 \%$ in 2015 , eggs - by $9.7 \%$, berries and grapes - by $4.3 \%$ and potatoes by $1.3 \%$. At the same time, the actual consumption of milk and dairy products increased by $2.4 \%$. The level of consumption of bread and bakery products, potato in 2015 exceeded the rationale.

The calculation of the adequacy of food consumption in terms of individual species made it possible to find that in 2015, only six types of food (bread and bakery products, poultry, eggs, vegetables and melons, potatoes and vegetable oil) per capita consumption was based on scientifically grounded level, or exceeded recommended rates. In other groups there was a lack of consumption, especially on products of animal origin, except for the consumption of eggs and egg products. Every day, Ukrainians consumed an average of 84 grams of protein, which is one of the lowest rates among the EU countries and $18 \%$ less than the average level of this indicator in developed countries (103 grams per day) [2]. It should be noted that meeting the needs of the population in the main food products, within its purchasing power, was provided, mainly due to domestic production.

The solution of the food supply of the country will be considered in the context of the justified need for the main components of the resource supply of agri-food production and its rational use. As you know, the volume of agricultural production depends on the aggregate of productive resources. Since it is difficult to take into account all the factors affecting the production of agricultural products, then for the construction of the empirical production function, we select the most influential ones.

So, in the field of plant growing - the cost of capital (K) (fixed assets, current assets), the cost of labor resources (L) and arable land (S). In livestock - the cost of capital (fixed assets, current assets), the cost of labor resources spent and the number of conditional livestock and poultry [3].

We will conduct an analysis based on the neo-classical production function of Cobb-Douglas according to the data of agricultural enterprises of Ukraine for 2003-2015.

We construct the neoclassical production function of Cobb-Douglas:

$$
P=A K^{\alpha} * L^{\beta} * S^{\kappa} * e^{\eta},
$$

where $\mathrm{P}$ - income (revenue) from the sale of crop production (livestock); $\mathrm{K}$ - cost of capital; $\mathrm{L}$ - number of employees in the industry; $\mathrm{S}$ - area of arable land (plant growing) and conditional livestock (livestock); $\mathrm{e}$ - hour; $\mathrm{A}, \alpha, \beta, \kappa, \eta$ are parameters of the model.

The process of constructing a production function was carried out in the following sequence:

In the first stage, we perform the linearization of the production function and reduce it to linear form. Linearization is performed in two steps. Prologarithm for both parts of the equation:

$$
\ln P=\ln a_{0}+\alpha \ln K+\beta \ln L+\kappa \ln S+\eta \ln e,
$$

Let's replace the variables: 


$$
Y=\ln P ; \quad x_{1}=\ln K ; \quad x_{2}=\ln L ; \quad x_{3}=\ln S
$$

As a result, the nonlinear multiplicative production function is reduced to the following linear one:

$$
y=b_{0}+b_{1} x_{1}+b_{2} x_{2}+b_{3} x_{3}+b_{4} x_{4} \text {, }
$$

\section{where the parameters of linear and nonlinear forms are related by the} following relations:

$$
b_{0}=\ln a_{0}, \quad b_{1}=\alpha, \quad b_{2}=\beta, \quad b_{3}=\kappa,
$$

In the second stage, we construct models of multiple linear regression and estimate the parameters of the model by the method of least squares.

As a result of regression analysis we get the following indicators: R2 is 0,992 for plant growing and 0,978 for livestock, which indicates a tight functional dependence of income on the studied types of resources.

Fisher's calculation criteria $F=121,43$ and $F=43,48$ exceed the table value of Fisher's criterion $F$ $(0,05 ; 2 ; 26)=3,42$, that is, the regression equations are significant, therefore, the dependent variable $Y$ is studied, which is included in the regression model variables.

On the basis of the obtained data it is possible to deduce the function of Cobb-Douglas:

in plant growing:

$$
\ln (y)=-4,2998+0,5997 \ln (K)+0,5816 \ln (L)+0,1503 \ln (S)-0,00001(e)+\varepsilon,
$$

in animal husbandry:

$$
\ln (y)=-5,1863+0,934 \ln (K)+0,1356 \ln (L)+0,5155 \ln (S)-0,00002(e)+\varepsilon,
$$

On the basis of the obtained model it is possible to deduce the production functions of Cobb-Douglas by means of an exhibit:

\section{in plant growing:}

$$
Y=0,013571 K^{0,5997} L^{0,5816} S^{0,1503} e^{-0,00001} \text {, }
$$

\section{in animal husbandry:}

$$
Y=0,00559 K^{0,934} L^{0,1356} S^{0,5155} e^{-0,00002}
$$

As a result of the obtained models, one can conclude that there is an increasing effect on the scale, since the sum of the coefficients $\alpha, \beta, \kappa$ exceeds 1 . This indicates that, provided that the factors $\mathrm{K}, \mathrm{L}$, and $\mathrm{S}$ increase in a certain proportion, then the result $\mathrm{P}$ increases in a larger proportion, that is, there is a synergistic effect.

As a result of the obtained models, one can conclude that there is an increasing effect on the scale, since the sum of the coefficients,, exceeds 1 . This indicates that, provided that the factors $K, L$, and $S$ increase in a certain proportion, then the result $P$ increases in a larger proportion, that is, there is a synergistic effect.

As the calculations show, the cost of capital has a decisive influence on the performance indicator. Thus, with an increase in capital in crop production by $1 \%$, the proceeds from the sale of crop production will increase by $0,6 \%$, and in animal husbandry - by $0,9 \%$.

The resulting model can be used to predict future output figures based on known or expected values of capital and labor. Obviously, the forecast demand for productive capital can be determined on the basis of the use of investment norms per unit of output, which will allow for the development of forecast scenarios of production volumes. 
We substantiated the scenarios of the development of domestic agricultural production, focused on providing the population of the country with food products in three variants (Table 1).

Table 1. Calculation of the forecast commodity supply of the main types of foodstuffs in Ukraine,\%

\begin{tabular}{|c|c|c|c|c|c|c|}
\hline \multirow{2}{*}{ Types of food } & \multicolumn{2}{|c|}{ I version } & \multicolumn{2}{|c|}{ II version } & \multicolumn{2}{|c|}{ III version } \\
\hline & $\begin{array}{l}\text { Farms } \\
\text { people }\end{array}$ & $\begin{array}{l}\text { Agricultural } \\
\text { enterprises }\end{array}$ & $\begin{array}{l}\text { Farms } \\
\text { people }\end{array}$ & $\begin{array}{l}\text { Agricultural } \\
\text { enterprises }\end{array}$ & $\begin{array}{l}\text { Farms } \\
\text { people }\end{array}$ & $\begin{array}{l}\text { Agricultural } \\
\text { enterprises }\end{array}$ \\
\hline $\begin{array}{l}\text { Bread and bakery } \\
\text { products }\end{array}$ & 24,3 & 75,7 & 18,4 & 81,6 & 2,8 & 97,2 \\
\hline Beef & 66,4 & 33,6 & 22 & 78,0 & 14,4 & 85,6 \\
\hline Pork & 56,9 & 43,1 & 45,6 & 54,4 & 27,6 & 72,4 \\
\hline Bird meat & 45,8 & 54,2 & 21,4 & 78,6 & 2,2 & 97,8 \\
\hline $\begin{array}{l}\text { Milk and dairy } \\
\text { products }\end{array}$ & 60,9 & 39,1 & 39 & 61,0 & 16,1 & 83,9 \\
\hline Eggs & 47,1 & 52,9 & 23,5 & 76,5 & 4,7 & 95,3 \\
\hline $\begin{array}{l}\text { Vegetables and } \\
\text { melons }\end{array}$ & 89,3 & 10,7 & 83,1 & 16,9 & 26,9 & 73,1 \\
\hline $\begin{array}{l}\text { Fruits, berries } \\
\text { and grapes }\end{array}$ & 88,2 & 11,8 & 81,8 & 18,2 & 53,6 & 46,4 \\
\hline Potato & 98,8 & 1,2 & 58,6 & 41,4 & 32,9 & 67,1 \\
\hline Sugar & 21,5 & 78,5 & 12,2 & 87,8 & 0,01 & 99,99 \\
\hline $\begin{array}{l}\text { Vegetable oil of } \\
\text { all kinds }\end{array}$ & 21,2 & 78,8 & 12,5 & 87,5 & 2,4 & 97,6 \\
\hline
\end{tabular}

Source: author's own calculations.

The first option involves the production of agrarian products to provide food to the population of the country according to the norms provided by the consumer "basket"; The second option involves meeting the needs of the population in food based on rational physiological standards; The third option involves the production of products for the population in accordance with the norms provided by the Agricultural Development Strategy of Ukraine for the period up to 2025. At the same time, when calculating the volume of production of the main types of food, the potential opportunities offered by the households and agricultural enterprises of various forms of management and ownership were considered.

Based on the results of the study, a hypothesis was adopted that, in the conditions of the deterioration of the socio-economic situation in the country, the share in the structure of agricultural production of households is increasing. According to the chosen variants, we determined the estimated production volumes of the main types of agricultural products to meet the country's needs for achieving food security of the country (Table 2).

Table 2. Estimated need for production of the main types of food, thousand tons

\begin{tabular}{|l|c|c|c|}
\hline \multicolumn{1}{|c|}{ Types of food } & I version & II version & III version \\
\hline Bread and bakery products & 8625 & 8119 & 80000 \\
\hline Beef & 709 & 2058 & 630 \\
\hline Pork & 1839 & 2625 & 1750 \\
\hline Bird meat & 1360 & 2094 & 1510 \\
\hline Milk and dairy products & 6929 & 20035 & 16000 \\
\hline Eggs, million pieces & 9966 & 15764 & 20900 \\
\hline Vegetables and melons & 4983 & 8460 & 18534 \\
\hline Fruits, berries and grapes & 2899 & 4566 & 3400 \\
\hline Potato & 4304 & 6853 & 22000 \\
\hline Sugar & 1676 & 1739 & 17000 \\
\hline Vegetable oil of all kinds & 531 & 1205 & 10490 \\
\hline
\end{tabular}

Source: author's own calculations. 
Obviously, ensuring the country's food security can be achieved with the economic growth of agricultural production on the principles of sustainability, which involves modernization and updating of the material and technical base, the introduction of innovative resource-saving technologies, ensuring the expanded reproduction of productive resources, the development of the system of logistic marketing and harmonization of domestic regulatory legislation. quality and safety of products to the requirements of European [4].

At the same time, we have calculated a balanced need for the components of resource provision of production in the agrarian sector of the economy. Of course, providing advanced reproduction in agriculture requires regulatory maintenance of productive capital - means of production: buildings and constructions, transmission systems of supply (electric energy, gas, water, heat), machinery and equipment, vehicles, materials, various raw materials, energy carriers, and mineral fertilizers and other chemicals and labor resources. The purchase of which requires investment resources, the need for them can be determined on the basis of relevant cost standards, which in the current conditions have not yet been developed.

In order to determine the need for investment in the production of one ton of crop and livestock production, it is advisable to develop methodological approaches to the calculation of cost standards of capital, the essence of which is that in the first place the objects for which it is necessary to develop investment standards for their formation. Such objects in crop production, there are crops depending on their yield, it is expedient to calculate the norms of investment per hectare of crops and plantings, and on their basis determine the investment standards for the production of one ton of agricultural products. To calculate the investment needs for livestock industries, methodological approaches were grounded, which determined the requirements for production capital requirements per head of animals and poultry, depending on their productivity, as well as for the production of one ton of livestock products.

In calculating the regulatory requirement for investment capital in the production of livestock products, two options have been developed: optimistic - which can be realized under favorable natural and climatic conditions for the production of basic types of agricultural products and high level of technological support; pessimistic - in the worsening conditions for the cultivation of farm animals and the maintenance of animals, as well as the use in the production of extensive technologies [5]. Note that the calculation of the norm will be carried out on the basis of determining the requirements of the requirements for the basic, human, working capital.

An important component in determining the investment standard is the standard of direct investment in fixed assets, which consists of the amount of financial resources directed on the construction of an inactive part of fixed assets (buildings, structures, warehouses, equipment), the purchase of long-term biological assets (in plant growing - perennial plantations, in livestock - working and productive livestock), as well as the acquisition of mechanization facilities which, according to the methodology of accounting and financial reporting, also include to the main means [6]. In accordance with the current accounting standards, in particular, P (C) BO 7 "Fixed assets", we will assess the active and passive portion of fixed assets at present cost, and long-term biological assets using the methodological principles outlined in $P$ (C) BO 30 "Biological Assets " Thus, on the basis of the current accounting standard, the cost per heifer of the milk production line is 67 thousand $\mathrm{UAH}$ - with the purchase of outsourced organizations, the cost will be 35 thousand UAH / head, sows - 4,5-5 thousand UAH / head.

Practical experience of agricultural enterprises proves that in determining the value of direct investment in fixed capital in livestock farming, there is the notion of "cost of cattle-shedding", which characterizes the cost of space for one animal in a stockhouse. According to the results of the conducted research, the cost of cattle-sight depending on the production technology is: in dairy cattle - 3,5-8 thousand $\mathrm{UAH}$, meat - 4,3-7,9 thousand UAH, pig breeding - 2,5 thousand. UAH [7-8].

We believe that this indicator is an integral reflection of the cost of not only purchased fixed assets, but also the price of technology - an intangible asset that will be used in the production of certain types of livestock products. In determining the standard of direct investment in fixed capital in dairy and meat cattle breeding, as well as pig breeding, it is advisable to take into account the biological characteristics of 
animals. In this regard, the standard of value in fixed assets will consist of three main components: the cost of direct investment in fixed assets, long-term biological assets, depreciation and maintenance (Table 3).

Table 3. Calculation of the standard of fixed capital

\begin{tabular}{|c|c|c|c|c|c|}
\hline Product & Productivity & $\begin{array}{c}\text { Standard of } \\
\text { direct } \\
\text { investments } \\
\text { (cost of cattle- } \\
\text { breeding) }\end{array}$ & $\begin{array}{l}\text { Standard in } \\
\text { long-term } \\
\text { biological } \\
\text { assets }\end{array}$ & $\begin{array}{c}\text { Standard for } \\
\text { depreciation } \\
\text { and current } \\
\text { repairs }\end{array}$ & Total \\
\hline \multicolumn{6}{|c|}{ Optimistic variant } \\
\hline Milk, kg / head / year & 4000 & 5220 & 36600 & 504,4 & 42324,4 \\
\hline Cattle, g/ head / day & 0,6 & 6340 & 26981 & 568,8 & 33889,8 \\
\hline Pig, g/ head / day & 0,45 & 2179 & 5500 & 236,3 & 7915,3 \\
\hline Bird, g / head / day & 0,03 & 234 & - & 12,7 & 246,7 \\
\hline $\begin{array}{l}\text { Eggs, pieces / goal / } \\
\text { year }\end{array}$ & 300 & 98 & - & 2,2 & 100,2 \\
\hline \multicolumn{6}{|c|}{ Pessimistic variant } \\
\hline Milk, kg / head / year & 3325 & 6299 & 35690 & 667,2 & 42656,2 \\
\hline Cattle, g/ head / day & 0,45 & 8533 & 24980 & 646,4 & 34159,4 \\
\hline Pig, g/ head / day & 0,35 & 2313 & 5000 & 284,2 & 7597,2 \\
\hline Bird, g / head / day & 0,028 & 235 & - & 14 & 249 \\
\hline $\begin{array}{l}\text { Eggs, pieces / goal / } \\
\text { year }\end{array}$ & 275 & 101 & - & 2,7 & 103,7 \\
\hline
\end{tabular}

Source: author's own calculations.

It is established that in the crop production of the standard of direct investment in fixed assets has its own peculiarity and is determined on the basis of the standard of cost of fixed assets per 1 hectare of arable land. According to the results of the research by L.B. Hnatyshyn, he made $136997 \mathrm{UAH} /$ ha of arable land for the farms of the Lviv region [9]. In our opinion, this integral indicator reflects the level of needs of the crop sector in the main means. It should be noted that our calculations of norms are carried out only for the livestock sector, where it is necessary to take into account a more complex system of specific factors of its functioning.

The standard of human capital consists of two parts: the cost of living labor and its cost, taking into account the size of the single social contribution. The following factors are taken into account when determining the level of living expenses, in particular in livestock production: technological: multiplicity of works, type of feeding (dry, wet, liquid feed, feed mix), system or method of keeping animals, production direction, and destination, capacity of premises, type of equipment etc.; natural: species, sex, age of animals, duration of winter and summer periods, productivity; organizational and zootechnical: method of distribution of feed, removal of manure, cleaning of premises, drinking, the length of keeping animals, the conditions for their grazing; socio-economic: the duration of the working day, the working day, the form of distribution and cooperation of labor, the rights, responsibilities and responsibilities of performers. Different variants of the combination of the above factors include organizational and technological options for the implementation of work, which determine the magnitude of the standards of service [10].

Determination of the standard labor costs was based on the above factors, which were reflected in the technological maps for the cultivation of agricultural crops and animals. This takes into account the level of labor productivity of production processes in the production of agricultural products both in agricultural enterprises and households. The basis of the analytical base of the survey results of the research institute «Ukrprom agro provvnitsiya» was used.

The working capital standard is based on two values: the natural rates of their spending and the cost at the time of the calculation. It should be noted that there are certain features of the definition of the working capital standard in livestock, where the largest share is occupied by feed. According to the data of 2014 , the share of the cost of feed in the cost of meat production was: for the production of cattle - 
$56.1 \%$, pigs 63.6 , poultry $-66.2 \%$. According to the results of a questionnaire survey in the cost of livestock products produced in households, this share reaches $70-75 \%$. As is known, the cost of feed in the structure of the cost of these products is determined by two factors: the level of feed costs per unit of production and their price.

A generalized calculation of the investment standard for the production of basic livestock products is presented in table 4.

Table 4. Calculation of investment standards for the production of the main types of livestock products

\begin{tabular}{|l|c|c|c|c|c|c|c|c|}
\hline \multicolumn{1}{|c|}{ Product } & $\begin{array}{c}\text { Productivity } \\
\text { of farm } \\
\text { animals }\end{array}$ & $\begin{array}{c}\text { Human } \\
\text { capital } \\
\text { UAH / } \\
\text { Goal }\end{array}$ & $\begin{array}{c}\text { Working } \\
\text { capital } \\
\text { UAH / Goal }\end{array}$ & $\begin{array}{c}\text { Fixed } \\
\text { capital } \\
\text { UAH / } \\
\text { Goal }\end{array}$ & Total & $\begin{array}{c}\text { Labor } \\
\text { costsare } \\
\text { human- } \\
\text { year/t }\end{array}$ & $\begin{array}{c}\text { Feed } \\
\text { tons of } \\
\text { cor. } \\
\text { unit / t }\end{array}$ \\
\hline $\begin{array}{l}\text { Milk, kg / head / } \\
\text { year }\end{array}$ & 4000 & 5178 & 12304,4 & 42324,4 & 59806,8 & 60,3 & 1,1 \\
\hline $\begin{array}{l}\text { Cattle, g / head / } \\
\text { day }\end{array}$ & 0,6 & 1772,9 & 4810 & 33889,8 & 40472,7 & 480 & 9,8 \\
\hline Pig, g / head / day & 0,45 & 564,9 & 3636,5 & 7915,3 & 12116,7 & 175,8 & 5,4 \\
\hline $\begin{array}{l}\text { Bird, g / head / } \\
\text { day }\end{array}$ & 0,03 & 16,9 & 168,1 & 246,7 & 431,7 & 450 & 3,60 \\
\hline $\begin{array}{l}\text { Eggs, pieces / } \\
\text { goal / year }\end{array}$ & 300 & 1,5 & 11,9 & 100,2 & 113,6 & 3,2 & 0,14 \\
\hline $\begin{array}{l}\text { Milk, kg / head / } \\
\text { year }\end{array}$ & 3325 & 5341,7 & 11808,8 & 42656,2 & 59806,7 & 75,4 & 1,3 \\
\hline $\begin{array}{l}\text { Cattle, g / head / } \\
\text { day }\end{array}$ & 0,45 & 1418,3 & 4174,6 & 34159,4 & 39752,3 & 480 & 11,0 \\
\hline \begin{tabular}{l} 
Pig, g / head / day \\
\hline
\end{tabular} & 0,35 & 482,6 & 3589,7 & 7597,2 & 11669,5 & 189,2 & 7,5 \\
\hline $\begin{array}{l}\text { Bird, g / head / } \\
\text { day }\end{array}$ & 0,028 & 17,4 & 185,6 & 249 & 452 & 68,4 & 4,22 \\
\hline $\begin{array}{l}\text { Eggs, pieces / } \\
\text { goal / year }\end{array}$ & 275 & 1,8 & 14,1 & 103,7 & 119,6 & 3,8 & 0,17 \\
\hline
\end{tabular}

Source: author's own calculations.

We have calculated the rates of advanced productive capital required to produce one ton of livestock products (Table 5), as used in determining the volume of investment in implementing the program to achieve rational consumption norms, the food basket and the parameters of the strategic program.

According to the results of Table 5 in accordance with the project of the strategy of agricultural production in Ukraine for the period up to 2025 , for most types of livestock products, the level of rational consumption standards, excluding egg production, will not be reached.

It is obvious that ensuring satisfaction of the needs of the population at the level of rational norms requires, on the one hand, balanced resource provision and its effective use, and on the other hand, increasing the purchasing power of the population. 
Table 5. Determination of the need for investments in the production of the main types of livestock products according to the relevant programs

\begin{tabular}{|c|c|c|c|c|c|c|c|c|}
\hline \multirow{2}{*}{ Product } & \multirow{2}{*}{ Scenario } & \multirow{2}{*}{$\begin{array}{c}\text { Standard } \\
\text { UAH / t }\end{array}$} & \multicolumn{2}{|c|}{$\begin{array}{l}\text { Rational * } \\
\text { consumption } \\
\text { standards }\end{array}$} & \multicolumn{2}{|c|}{$\begin{array}{l}\text { Norms * } \\
\text { according to the } \\
\text { parameters of the } \\
\text { consumer basket }\end{array}$} & \multicolumn{2}{|c|}{$\begin{array}{l}\text { According to the } \\
\text { development } \\
\text { strategy }\end{array}$} \\
\hline & & & $\begin{array}{c}\text { thousan } \\
\text { ds of } \\
\text { tons }\end{array}$ & $\begin{array}{c}\mathrm{UAH} \\
\text { million }\end{array}$ & $\begin{array}{c}\text { thousa } \\
\text { nds of } \\
\text { tons }\end{array}$ & $\begin{array}{c}\text { UAH } \\
\text { million }\end{array}$ & $\begin{array}{c}\text { thousa } \\
\text { nds of } \\
\text { tons }\end{array}$ & $\begin{array}{c}\text { UAH } \\
\text { million }\end{array}$ \\
\hline \multirow[t]{2}{*}{ Milk } & opt & 14951,7 & \multirow{2}{*}{17730} & 264177 & \multirow{2}{*}{6929} & 103242 & \multirow{2}{*}{16000} & 238400 \\
\hline & pess & 18123,2 & & 320913 & & 125415 & & 289600 \\
\hline \multirow[t]{2}{*}{ Meat of cattle } & opt & 184807 & \multirow{2}{*}{1805} & 333930 & \multirow{2}{*}{708} & 130980 & \multirow{2}{*}{630} & 116550 \\
\hline & pess & 243392 & & 438620 & & 172040 & & 153090 \\
\hline \multirow[t]{2}{*}{ Pork Meat } & opt & 73882,3 & \multirow{2}{*}{2344} & 172987 & \multirow{2}{*}{1839} & 135718 & \multirow{2}{*}{1750} & 129150 \\
\hline & pess & 91885,8 & & 215414 & & 169004 & & 160825 \\
\hline \multirow[t]{2}{*}{ Bird meat } & opt & 43170 & \multirow{2}{*}{1886} & 81475 & \multirow{2}{*}{1360} & 58752 & \multirow{2}{*}{1510} & 65232 \\
\hline & pess & 45200 & & 85472 & & 61472 & & 68252 \\
\hline \multirow[t]{2}{*}{ Eggs } & opt & 7973 & \multirow{2}{*}{770} & 6083 & \multirow{2}{*}{589} & 4653 & \multirow{2}{*}{1191} & 9409 \\
\hline & pess & 6682 & & 5313 & & 4064 & & 8218 \\
\hline
\end{tabular}

* Calculation of physical volumes of necessary livestock products was based on established consumption norms (rational and minimum), total population (45.3 million people) and corresponding coefficients of conversion of processed products into physical units.

Source: author's own calculations.

\section{Conclusions}

The results of the conducted research allow us to conclude that the proposed methodology for determining the normative needs of agriculture in investment resources for the production of products of the livestock sector with a slight adjustment to the technology of keeping livestock and poultry can be used to achieve a balance of resource support for the production process based on the introduction of progressive resource-saving technologies and the modernization of industries in new innovative conditions, as well as in the development of the whole regional agricultural development programs within the framework of food security. The calculated requirements for investment needs should be the basis for developing tools for stimulating investment processes in certain livestock sectors, which will create conditions for their qualitative economic growth.

\section{Bibliography}

1. Pylypenko K.A. (2015). Models of Food Security of EU Member States. Economy of AIC. No. 3 (39). P. 50-55. [In Ukrainian].

2. Dudar B. (2016). Food Security of Ukraine and its Components in the Context of Economic Security of the State. TNEU Bulletin. No. 2. P. 20-31. [In Ukrainian].

3. Topol R., Walliser B. (2007). Cognitive Economics: New Trends. Elsevier Science. 278 p.

4. Nastich V.G. (2016). The current state of food security of Ukraine. Bulletin of the Berdyansk University of Management and Business. No. 3 (35). P. 30-34.

5. Baryshnikov N.G., Samygin D.Yu. (2013). Forecast scenarios for agricultural development in the region. Economist. No. 12. P. 77-85. [In Ukrainian].

6. Chornyi R.V., Voloshin R.V. (2010). Features of the process of investing in fixed capital of agricultural production. Innovative economy. No. 2 (16). P. 134-137. [In Ukrainian].

7. Levchenko N.V., Oglih V.V. (2012). Methods of assessing the investment attractiveness of agriculture in the regions of Ukraine in the context of strategic planning. Current problems of the economy. No. 8. P. 285. [In Ukrainian].

8. Loberg J. M., Hernandez C.E., Thierfelder T. et al. (2009). Weaning and separation in two steps - A way to decrease stress in dairy calves suckled by foster cows. Applied animal behaviour science. V. 111. № 1. P. 222-234. 
9. Gnatyshyn L.B. (2012). Normative methods for determining the needs of farms in technical means. Scientific herald of NLTU of Ukraine. Exp. 22.4. S. 134-140. [In Ukrainian].

10. Demchak I.M., Nechiporuk A.A., Nikitiuk D.M. et al. (2015). Methodological provisions and norms of labor productivity in animal husbandry. Kyiv: Scientific research institute "Ukragropromproduktyvnost". 534 p. [In Ukrainian]. 